\title{
Gonodactylellus spiridonovi sp.n., a new species of coral reef mantis shrimp from the Red Sea (Crustacea: Stomatopoda: Gonodactylidae)
}

\author{
Gonodactylellus spiridonovi sp.n., новый вид рифовых раков- \\ богомолов из Красного моря (Crustacea: Stomatopoda: \\ Gonodactylidae)
}

\author{
Shane T. Ahyong \\ Шэйн Т. Айонг
}

Australian Museum Research Institute, Australian Museum, 1 William St., Sydney, NSW 2010, Australia. E-mail: shane.ahyong@austmus.gov.au

School of Biological, Earth \& Environmental Sciences, University of New South Wales, Kensington, NSW 2052, Australia.

KEY WORDS: Crustacea, Stomatopoda, mantis shrimp, Red Sea, Indian Ocean.

КЛЮЧЕВЫЕ СЛОВА: Crustacea, Stomatopoda, раки-богомолы, Красное море, Индийский океан.

ABSTRACT. A new species of coral reef mantis shrimp of the genus Gonodactylellus spiridonovi sp.n. is described from the Red Sea, constituting the twentyfourh species in the genus and fourth from the northwestern Indian Ocean. The new species aligns with those species of Gonodactylellus having short accessory median carinae on the telson that do not extend anteriorly beyond the posterior one-third of the median carina and lacking dorsal spinules on the telson surface (G. annularis Erdmann et Manning, 1998, G. erdmanni Ahyong, 2001, G. incipiens (Lanchester, 1903) and G. viridis (Serène, 1954)) but is distinguished from all of the species by the shorter anterior submedian carina on the telson. A key to the species of Gonodactylellus from the northwestern Indian Ocean is provided.

How to cite this paper: Ahyong S.T. 2021. Gonodactylellus spiridonovi sp.n., a new species of coral reef mantis shrimp from the Red Sea (Crustacea: Stomatopoda: Gonodactylidae) // Arthropoda Selecta. Vol.30. No.3. P.295-298. doi: 10.15298/arthsel. 30.3.03

РЕЗЮМЕ. Новый вид раков-богомолов Gonodactylellus spiridonovi sp.n. описан с кораллового рифа из Красного моря, являясь двадцать четвертым видом в роде и четвертым из северо-западной части Индийского океана. Новый вид похож на виды рода Gonodactylellus, имеющими короткие дополнительные срединные карины на тельсоне, не выходящие вперед за заднюю треть срединного гребня и не имеющие дорсальных зубчиков на поверхности тельсона ( $G$. annularis Erdmann et Manning, 1998, G. erdmanni Ahyong, 2001, G. incipiens (Lanchester, 1903) и G. viridis (Serène, 1954)), но при этом отличается от всех указанных видов более коротким передним субмедиальнымгребнем на тельсоне. Приводится ключ к видам рода Gono- dactylellus из северо-западной части Индийского океана.

\section{Introduction}

The gonodactylid genus Gonodactylellus Manning, 1995, includes 23 comparatively small Indo-West Pacific species, usually TL $30 \mathrm{~mm}$ or less, that are abundant on tropical reefs in crevices in rock, coral, sponge, and biofouling [Ahyong, 2001, 2012, 2016]. The majority of species of Gonodactylellus occur in the western Pacific, but, to date, only three species of the genus have been recorded from the Red Sea and Persian Gulf, namely G. choprai Manning, 1968, G. demani (Henderson, 1893) and G. lanchesteri (Manning, 1967). A new species of Gonodactylellus is described herein from the region based on specimens collected from the Gulf of Aqaba and the Gulf of Aden.

\section{Materials and methods}

Morphological terminology follows Ahyong [2001] and Ahyong et al. [2008]. Total length (TL) is measured along the dorsal midline from the tip of the rostral plate to the apices of the submedian teeth of the telson. Carapace length (CL) is measured along the dorsal midline of the carapace and excludes the rostral plate. The abdominal-width carapace-length index (AWCLI) is given as $100 \times$ (width of abdominal somite 5)/CL. Specimens are deposited in the Senckenberg Museum Forschunginstitut, Frankfurt, Germany (SMF).

\section{Taxonomy}

Superfamily Gonodactyloidea Giesbrecht, 1910

Family Gonodactylidae Giesbrecht, 1910

Genus Gonodactylellus Manning, 1995 Gonodactylellus spiridonovi sp.n. Fig. 1. 


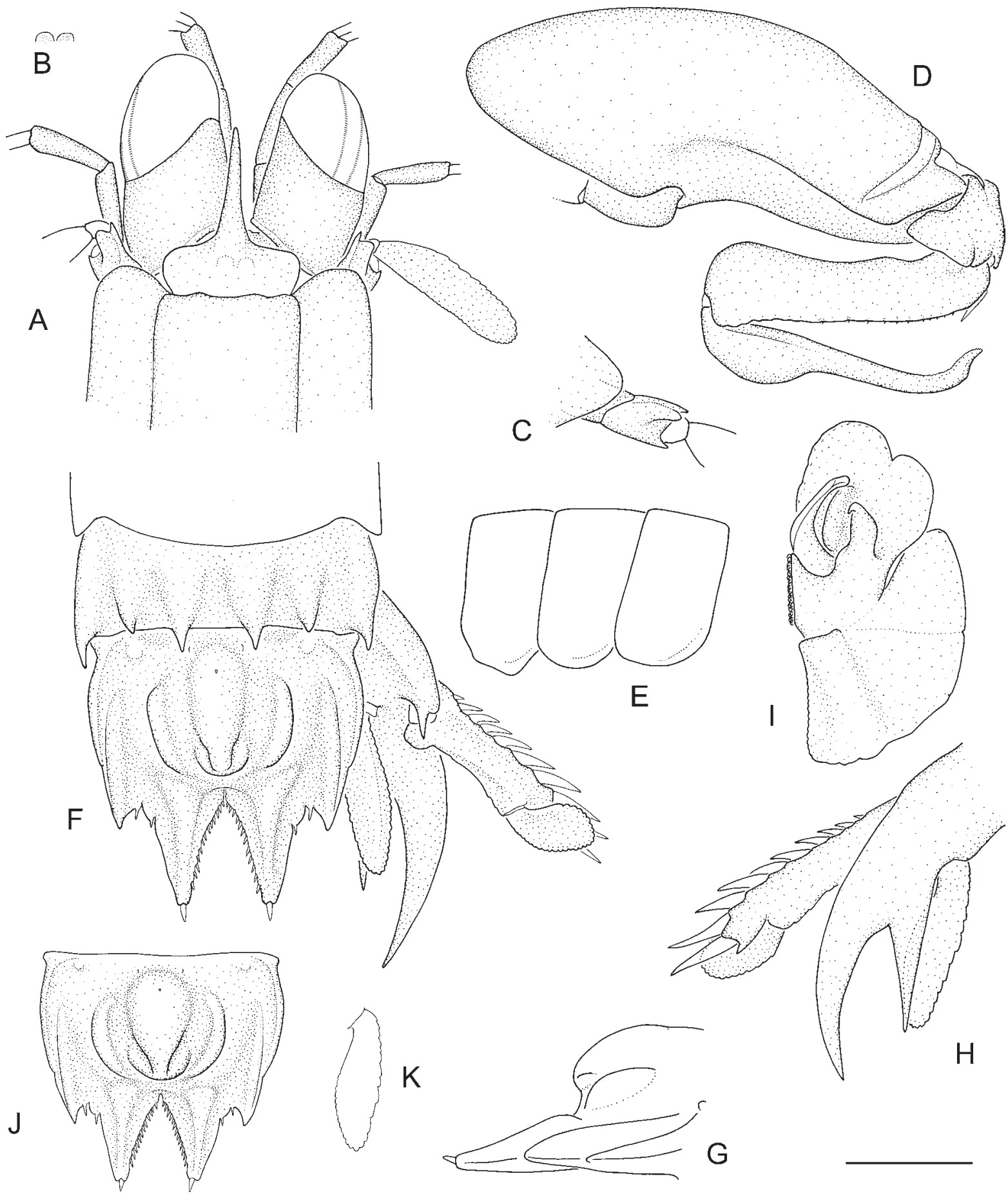

Fig. 1. Gonodactylellus spiridonovi sp.n.: A-I - male holotype, TL 14 mm, Gulf of Aqaba, SMF 37071; J-K - female paratype, TL $14 \mathrm{~mm}$, Gulf of Aden, SMF 37072. A - anterior cephalothorax; B — ocular scales; C - right antennal protopod; D - right raptorial claw; $\mathrm{E}$ - thoracic somites 6-8, right lateral view; $\mathrm{F}$ - posterior abdominal somites, telson and right uropod; $\mathrm{G}$ - telson, right lateral view; $\mathrm{H}$ - right uropod, ventral view; I — right pleopod 1 endopod, anterior view; $\mathrm{J}$ - telson, dorsal view; $\mathrm{K}$ - right uropodal endopod, ventral view. Scale: A-H, J, K $-1.0 \mathrm{~mm}, \mathrm{I}-0.5 \mathrm{~mm}$.

Рис. 1. Gonodactylellus spiridonovi sp.n.: A-I - голотип самец, TL 14 мм, залив Акаба, SMF 37071; J-K — паратип самка, TL 14 мм, Аденский залив, SMF 37072. А - передняя часть цефалоторакса; В - глазные чешуйки; C — правый протопод антенн; D правый коготь клешни; Е — грудные сомиты 6-8, вид справа сбоку; F — задние брюшные сомиты, тельсон и правый уропод; G тельсон, вид справа сбоку; Н - правый уропод, вид снизу; I — правый эндопод плеопод 1, вид снизу; J — тельсон, вид сверху; $\mathrm{K}$ правый эндопод уропод, вид снизу. Масштаб: А-H, J, K - 1,0 мм, I - 0,5 мм. 
?Gonodactylus incipiens. — Manning, 1990: 104 [not G. incipiens (Lanchester, 1903)].

MATERIAL EXAMINED. HOLOTYPE: SMF 37071, male (TL $14 \mathrm{~mm}$ ), Gulf of Aqaba, Aqaba, off Marine Science Station (MSS), 35 m, from dead Acropora, AQ52, coll. V. Neumann, 10.06.1995. PARATYPE: SMF 37072, 1 female (TL $14 \mathrm{~mm}$ ), Gulf of Aden, off Djibouti, $12^{\circ} 21.2-19.0^{\prime \prime} \mathrm{N}, 43^{\circ} 27.1-27.8^{\prime \prime} \mathrm{E}, 35-45$ m, RV Meteor, Me5-236Ku, 6.03.1987.

DIAGNOSIS. Ocular scales separate, apices rounded, together about as wide as base of rostral spine. Raptorial claw dactylus outer proximal margin without proximal notch in adults. Thoracic somite 6 lateral processes rounded ventrally, little wider than that of thoracic somite 7 . Pleopod 1 endopod with distinct lateral lobe on posterior endite. Telson median carina pyriform, tumid; distally unarmed; without dorsal spinules; emargination between submedian and intermediate teeth acute; accessory median carinae short, extending anteriorly to less than posterior one-third of median carina; anterior submedian carinae extending anteriorly almost to level of dorsal pit of median carina.

DESCRIPTION. Eyes elongate; cornea subconical, extending anteriorly beyond midlength but not to end of antennal peduncle segment 2. Ophthalmic somite anterior margin with small median tubercle. Ocular scales small, separate, rounded, together about as wide as base of rostral spine.

Antennular peduncle length $0.77-0.78 \mathrm{CL}$. Antennal protopod without papillae; with fixed, laterally flattened mesiodorsal spine; with short anteroventral spine. Antennal scale length $0.37-0.40 \mathrm{CL}$.

Rostral plate longer than wide; basal portion with almost transverse anterior margin, slightly sloping posteriorly; anterolateral angles rounded; lateral margins anteriorly divergent; median spine longer than base, without ventral keel.

Raptorial claw dactylus outer proximal margin without proximal notch in adults; propodus with proximal movable spine, opposable margin sparsely pectinate proximally.

Mandibular palp 3-segmented. Maxillipeds 1-5 each with epipod.

Thoracic somite 6 and 7 lateral processes rounded ventrally, that of somite 6 little wider than that of somite 7 . Thoracic somite 8 anterolateral margin rounded; sternal keel obsolete.

Pleopod 1 endopod with distinct lateral lobe on posterior 'endite'.

Abdominal somite 1-5 posterolateral angles unarmed. Abdominal somite 6 with posteriorly armed submedian, intermediate and lateral bosses; without ventrolateral spine anterior to uropodal articulation margin. AWCLI 753.

Telson as wide as or slightly wider than long, surface without dorsal spinules; with 12 or 13 spiniform submedian denticles. Submedian teeth unarmed dorsally, dorsal carina relatively slender. Intermediate teeth distinct, apices sharp, extending posteriorly to level of apices of inner intermediate denticles; intermediate carina slender, extending anteriorly beyond midlength of accessory median carina; emargination between submedian and intermediate teeth acute. Lateral teeth indicated by a shallow notch, apex angular to low, rounded, not projecting well off margin of telson. Median carina pyriform, tumid; distally unarmed. Accessory median carinae unarmed, extending anteriorly to less than posterior one-third of median carina. Anterior submedian carinae smooth, slightly arcuate, extending anteriorly almost to level of dorsal pit of median carina. Knob absent. Telson ventral surface without carinae on submedian or intermediate teeth.

Uropodal protopod terminal spines flattened, outer spine longer. Uropodal exopod proximal article outer margin with
9 or 10 movable spines, distalmost spine exceeding apex of distal article; inner margin setose; distal margin with fixed ventral spine; exopod distal segment rounded, entire margin setose. Uropodal endopod narrow, length 3.10-3.65 width; with low dorsolateral swelling; entire margin setose.

COLOURATION. Completed faded in alcohol.

MEASUREMENTS. Male holotype: TL 14 mm, CL 3.24 $\mathrm{mm}$, antennular peduncle $2.51 \mathrm{~mm}$, antennal scale $1.31 \mathrm{~mm}$, abdominal somite 5 width $2.44 \mathrm{~mm}$. Female paratype: TL 14 $\mathrm{mm}$, CL $2.79 \mathrm{~mm}$, antennular peduncle $2.19 \mathrm{~mm}$, antennal scale $1.02 \mathrm{~mm}$, abdominal somite 5 width $2.10 \mathrm{~mm}$

ETYMOLOGY. It is a pleasure to name this species in honour of Vassily Spiridonov, in acknowledgement of his untimely loss and of his excellent contributions to carcinology, especially that of the Indian Ocean.

REMARKS. Gonodactylellus spiridonovi sp.n. aligns with those species in the genus having short accessory median carinae on the telson that do not extend anteriorly beyond the posterior one-third of the median carina and lacking dorsal spinules on the telson surface: G. annularis Erdmann et Manning, 1998, G. erdmanni Ahyong, 2001, G. incipiens (Lanchester, 1903) and G. viridis (Serène, 1954). Gonodactylellus spiridonovi sp.n. differs from each of these in its shorter anterior submedian telson carinae, which reach anteriorly only almost as far as the level of the dorsal pit of the median carina, rather than distinctly beyond. Gonodactylellus spiridonovi sp.n. further differs from G. annularis in having an acute (versus almost right-angled) emargination between the submedian and intermediate teeth of the telson (Fig. 1F, J; Ahyong [2001]: fig. 22F) and a well-developed (versus undeveloped) lateral lobe on the posterior endite of the male pleopod 1 endopod (Fig. 1I; Ahyong [2001]: fig. 22J). From G. erdmanni, G. spiridonovi sp.n. further differs in the lower margin of thoracic somite 6 being rounded and narrower (Fig. 1E), rather than wide and truncate [Ahyong, 2001: 24D], and a less distinct lateral tooth on the telson (Fig. 1F, J), which is set off further from the margin in $G$. erdmanni (see Ahyong [2001]: fig. 24). In the shape and width of the lower margin of thoracic somite 6, G. spiridonovi sp.n. resembles $G$. viridis and $G$. incipiens, but in addition to the shorter anterior submedian carinae of the telson, further differs in the smaller ocular scales (together about as wide as base of rostral spine versus distinctly wider) (Fig. 1A, B; Ahyong [2001]: fig. 31B)]. Gonodactylellus spiridonovi sp.n. is currently known from 35-45 m depth and so may differ ecologically from $G$. annularis, G. erdmanni, G. incipiens and $G$. viridis, which typically occur at depths much less than $20 \mathrm{~m}$ [Ahyong, 2001].

Within Gonodactylellus, G. spiridonovi sp.n. closely resembles $G$. incipiens in general telson shape and curved anterior submedian carinae (Fig. 1F, J; Ahyong [2001]: fig. $26 \mathrm{E}$ ), and would key as such according to previous works (e.g., Manning [1967, 1995]; Ahyong [2001]). Although $G$. incipiens was long thought to be widespread in the IndoWest Pacific [Manning, 1967, 1995], Ahyong [2001], after revising type and other material of the species, showed that it is restricted to the oceanic western Pacific, from localities between the Marshall Islands, Phoenix Islands and the Great Barrier Reef, eastern Australia. Most other previous reports of $G$. incipiens were misidentifications of G. erdmanni (e.g., Manning [1966, 1991, 1995]), G. affinis (De Man, 1902) (e.g., Tattersall [1906]; Moosa [1991]), G. kumei Ahyong, 2012 [Moosa, 1991], G. rubriguttatus Erdmann et Manning, 1998 (e.g., Moosa [1991]) and G. viridis [Moosa, 1991; Manning, 1995]. Likewise, Manning's [1990] report of $G$. 
incipiens from Oman is also a misidentification, herein referred to G. spiridonovi.

Gonodactyllus spiridonovi sp.n. is the fourth species of the genus confirmed from the northwestern Indian Ocean; they are distinguished in the key below.

DISTRIBUTION. Presently known only from the Gulf of Aqaba and Gulf of Aden, and possibly Oman; 35-45 m.

KEY TO SPECIES OF GONODACTYLELLUS FROM THE NORTHWESTERN INDIAN OCEAN

1. Telson dorsal surface with numerous spinules .... 2

- Telson dorsal surface without spinules

2. Uropodal endopod inner margin with few setae at proximal end, otherwise smooth, glabrous G. demani (Henderson, 1893)

- Uropodal endopod inner margin fully with setae G. lanchesteri (Manning, 1967)

3. Telson accessory median carinae extending beyond posterior one-third of median carina; apices of lateral teeth not extending posteriorly to apices of inner intermediate denticle. Uropodal exopod proximal article without fixed distal spine ........................... choprai (Manning, 1967)

- Telson accessory median carinae short, not extending anteriorly beyond posterior one-third of median carina; apices of lateral teeth extending to level of apices of inner intermediate denticle. Uropodal exopod proximal article with fixed distal spine ......... G. spiridonovi sp.n.

Acknowledgments. Thanks go to the late Michael Türkay for bringing the studied specimens to my attention, Ivan Marin for inviting this contribution, and Zdeněk Duriš for constructive comments on the manuscript.

\section{References}

Ahyong S.T. 2001. Revision of the Australian Stomatopod Crustacea // Records of the Australian Museum. Suppl.26. P.1-326.

Ahyong S.T. 2012. Stomatopod Crustacea of the KUMEJIMA 2009 Expedition, Japan // Zootaxa. Vol.3367. P.232-251.

Ahyong S.T. 2016. Results of the Comprehensive Marine Biodiversity Survey International Workshops 2012 and 2013: Stomatopod Crustacea // Raffles Bulletin of Zoology. Supplt.34. P. 455-469.

Ahyong S.T., Chan T.-Y., Liao Y.-C. 2008. A Catalog of the Mantis Shrimps (Stomatopoda) of Taiwan. Taipei: National Taiwan Ocean University, Keelung, Taiwan, R.O.C. 191 pp.

De Man J.G. 1902. Die von Herrn Professor Kükenthal im Indischen Archipel gesammelten Dekapoden und Stomatopoden //
Kükenthal W. (Hrsg.). Ergebnisse einer zoologischen Forschungsreise in den Molukken und Borneo. Abhandlungen der Senckenbergischen Naturforschenden Gesellschaft. Bd.25. S.467-929, pls.19-27.

Erdmann M.V., Manning R.B. 1998. Preliminary descriptions of nine new stomatopod crustaceans from coral reef habitats in Indonesia and Australia // Raffles Bulletin of Zoology. Vol.46. P.615-626.

Giesbrecht W. 1910. Stomatopoden, Erster Theil // Fauna und Flora des Golfes von Neapel. Bd.33. S.i-vii, 1-239, pl.1-11.

Henderson J.R. 1893. A contribution to Indian Carcinology // Transactions of the Linnean Society of London. Ser.2 (Zoology). Vol.5. No.10. P.325-458

Lanchester W.F. 1903. Stomatopoda, with an account of the varieties of Gonodactylus chiragra. Marine Crustaceans VIII // J.S. Gardiner (ed.). The fauna and geography of the Maldive and Laccadive Archipelagoes: being the account of the work carried on and of the collections made by an expedition during the years 1899 and 1900. Vol.1. P.444-459.

Manning R.B. 1966. Notes on some Australian and New Zealand stomatopod Crustacea, with an account of the species collected by the Fisheries Investigation Ship Endeavour // Records of the Australian Museum. Vol.27. P.79-137.

Manning R.B. 1967. Notes on the demanii section of the genus Gonodactylus Berthold with descriptions of three new species // Proceedings of the United States National Museum. Vol.123. P.1-27.

Manning R.B. 1990. Stomatopod Crustacea from the Persian Gulf, with the description of a new Manningia // Steenstrupia. Vol.16. No.6. P.93-108.

Manning R.B. 1991. Stomatopod Crustacea collected by the Galathea Expedition, 1950-1952, with a list of Stomatopoda known from depths below 400 meters // Smithsonian Contributions to Zoology. Vol.521. P.1-18.

Manning R.B. 1995. Stomatopod Crustacea of Vietnam: the legacy of Raoul Serène // Crustacean Research. Special number 4. P.1-339.

Moosa M.K. 1991. The Stomatopoda of New Caledonia and Chesterfield Islands // Richer de Forges B. (ed.). Le benthos de fonds meubles des lagons de Nouvelle-Calédonie. Editions de l'ORSTOM, Paris. P.149-219.

Serène R. 1954. Observations biologiques sur les stomatopodes // Mémoires de 1'Institut Océanographique de Nhatrang. Vol.8. No.1-93. Pls.91-100.

Tattersall W.M. 1906. Report on the Leptostraca, Schizopoda and Stomatopoda collected by Professor Herdman, at Ceylon, in 1902. Supplementary Report 33 // Herdman W.A. (ed.). Report to the Government of Ceylon on the pearl oyster fisheries of the Gulf of Manaar. Vol.5. P.159-188.

Responsible editor I.N. Marin 